\title{
Pre-service teachers' perceptions related to the distance teacher education learning environment and community of inquiry
}

\author{
Melike Özüdoğru \\ Manisa Celal Bayar University, Turkey
}

\begin{abstract}
This study aimed to reveal pre-service teachers' perceptions of Distance Education Learning Environment and Community of Inquiry according to gender and their departments and also clarify the relationship among these two sets. The research was designed according to relational survey research and crosssectional data were collected from 262 volunteer pre-service teachers. In this study, the Distance Education Learning Environment Survey (DELES) and the Community of Inquiry (CoI) Inventory were implemented to collect data. In order to investigate whether there were differences among the perceptions of pre-service teachers according to the sub-dimensions of their DELES and CoI variables, multivariate analysis of variance was conducted. In addition, Canonical Correlation was performed to investigate the relationship between the DELES and CoI variable sets in a teacher training institution. The results revealed that female pre-service teachers exhibited considerably greater teaching presence and cognitive presence scores than males. However, no significant differences were determined in pre-service teachers' perceptions of distance teacher education learning environments and the CoI according to their departments. Based on the results, teaching presence was found a core factor and the perceived social and cognitive presence was related to mild instructor support, relevant instruction, authentic, active learning, student interaction and collaboration, and autonomy properties of distance education teacher training classroom environments.
\end{abstract}

Keywords: Community of inquiry; Distance education learning environment; Pre-service teachers; Teacher training environment

Article History: Submitted 29 June 2021; Revised 23 October 2021; Published online 11 November 2021

\section{Introduction}

Since March 2020, universities have switched to distance learning to meet students' learning demands due to the pandemic's global impact. However, in almost all countries, the transformation of the curriculum to distance learning was very rapid, rather than a planned model to sustain education, and this process was termed emergency remote teaching (Almaiah et al., 2020; Baran \& Alzoubi, 2020; Carrillo \& Flores, 2020; Ferri et al., 2020; Hodges et al., 2020; Long et al., 2021). The courses were conducted online without any face-to-face connection (Arik, 2021; Carrillo \& Flores, 2020; Ferri et al., 2020; Gelles et al., 2020; Hodges et al., 2020; Long et al., 2021). According

Address of Corresponding Author

Melike Özüdoğru, PhD, Faculty of Education, Department of Curriculum and Instruction, 45190, Demirci, Manisa, Turkey.

$\triangle$ ozudogru123@gmail.com

0000-0002-7478-3576

How to cite: Özüdoğru, M. (2021). Pre-service teachers' perceptions related to the distance teacher education learning environment and community of inquiry. Journal of Pedagogical Research, 5(4), 43-61. https:/ / doi.org/10.33902/JPR.2021472945 
to Hodges et al. (2020), instructors may feel compelled to invent rapid answers in these situations. However, in distance education learning environments, the organization of courses, and studentteacher interaction are more important because of conducting the teaching-learning process through technology (Ferri et al., 2020; Garrison et al., 2010; Henderson et al., 2009; Shea et al., 2012; Snodin, 2013). Almaiah et al. (2020) mentioned course design issues as one of the important challenges for the successful distance learning process during the pandemic. Similarly, Ferri et al. (2020) stated learners' lack of engagement and teachers' shortcomings in generating meaning through sustaining instruction within an online community of inquiry as obstacles related to the design of instruction during emergency remote teaching.

The concepts such as instructor support, authentic, active, autonomy supportive, and personally relevant instruction, student-teacher interaction, and student collaboration are related to distance education learning environments and contribute to the effective distance education communities called as Community of Inquiry (CoI), which was developed by Garrison et al. (2000). An assumption underpinning this $\mathrm{CoI}$ Model is that an environment should include three core elements social, cognitive and teaching presence to achieve higher learning (Bangert, 2009; Rubin et al., 2013; Rourke \& Kanuka, 2009; Swan et al., 2009). Instructors and course designers need to understand the perceptions of learners in distance education learning environments and how these perceptions influence the perceived community to create deep and meaningful learning experiences (Lim \& Richardson, 2020). The study conducted by Louder (2011) investigated different variables of distance education learning environments and the alignment of these variables with the CoI framework, which was shown in Figure 1.

Figure 1

The alignment of DELES and CoI Variables

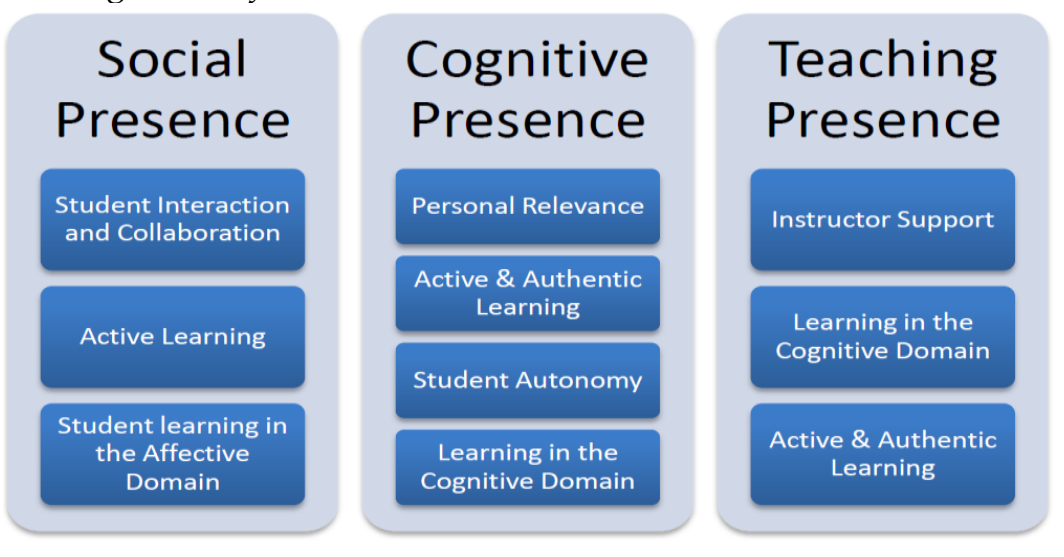

Note. Adapted from Louder (2011) p. 26.

Anderson et al. (2001) stressed the active existence, intervention, and facilitation of teachers to achieve effective and fruitful instruction related to 'teaching presence'. According to Figure 1, teaching presence which begins even before the courses commence as teachers act as instructional designers and is related to instructor support. Teachers plan the instruction, including organizing the aims and goals to be employed, content, instructional procedures, evaluation, time, etc., facilitate and guide the teaching-learning process to attain outcomes that are significant for learners and rewarding educationally (Anderson et al., 2001; Arbaugh \& Hwang, 2006; Shea et al., 2010). Garrison et al. (2000) stated that teaching presence is generally perceived as the role and function of the instructor, although it may be shared with learners. Aldridge et al. (2013) stated that teachers' relationships with learners are integral to their success and the creation of collaborative learning environments. As stated by Chou and Liu (2005), teachers are expected to facilitate learning by designing personally relevant and active courses, which encourage learners to participate in various tasks and discussions. In this sense, Baran and Alzoubi (2020) included short instructor videos with learners to establish a teaching presence in an effective online community of inquiry. Carrillo and Flores (2020) also emphasized the instructor's facilitation of 
both the instruction and evaluation processes, as well as the provision of timely, constructive, and detailed feedback at various phases of the learning process. The instructor's presence in the classroom is favourably associated to overall student performance in distant education learning environments, according to the study conducted by Mullen and Tallent-Runnels (2006). In addition, teaching presence is reflected during evaluation process by integrating various online evaluation methods such as self-assessment, authentic assessments, portfolios, and collaborative peer assessments besides traditional methods of assessing students, such as examinations and quizzes (Palloff \& Pratt, 2009).

In distance education classes, social interaction is limited by time and access, but there is a need for effective social interactions and a sense of presence in distance education classes (Palloff \& Pratt, 1999). In distance education settings, participants can become a part of a social milieu by expressing their ideas, views, values, and feelings about course topics (Swan et al., 2009). Moreover, starting communication, asking questions, answering them, expressions of praise and appreciation, calling one by his/her name, salutations, mutual awareness and mutual exchange of information are some of the indicators of social presence in distance education classes (Diaz et al, 2010; Shea et al., 2010; Traphagan et al., 2010). These are also the signs of interaction and collaboration among learners and they were stated as some of the necessary components of thriving distance education environments (Bian, et al., 2018; Knight \& Brame, 2018; Walker \& Fraser, 2005) and related to 'social presence' dimension of CoI. In the literature, it was stated that if student interaction and collaboration property of the classroom environment is emphasized, the cognitive and affective outcomes of learners become more favorable (Abeysekera \& Dawson, 2015). In this way, as displayed by Carlon et al. (2012), learners can express themselves better, discuss easily, think in-depth and inquire critically, which are the properties of the 'cognitive presence' of the CoI model.

Garrison et al. (2000) defined cognitive presence as the construction of meaning through reflection, discourse, and critical thinking. In the existence of cognitive presence, learners feel puzzled as a result of an experience or a problem. Then, they search for information to comprehend the situation or problem (Akyol et al., 2009; Arbaugh, 2007). Following these steps, learners begin to relate concepts with each other critically and propose hypotheses, exchange information, suggest alternative ideas, brainstorm on concepts, assertions, find evidence and elaborate on concepts and hypotheses (Akyol et al., 2009; Bangert, 2009; Stein, et al., 2007).

These cognitive processes require learners to take responsibility for their learning and control of their learning process related to the student autonomy property of the classroom environment, as shown in Figure 1. By shifting instruction from traditional to distance education, the flexibility of a technology-rich learning environment, such as planning when, how much, and where to study, transforms the responsibility of learning to learners (Ar1k, 2021; Chou \& Liu, 2005; Gelles et al., 2020; Smith, 2000; Vonderwell et al., 2007). Moreover, as the signs of cognitive presence, the learning community passes through compelling learning experiences through summarizing common ideas, making some of the conflicting ideas and misconceptions clear to arrive at a consensus, adding information from different sources, and providing feedback (Arbaugh \& Hwang, 2006; Garrison et al., 2010; Shea et al., 2005; Shea et al., 2010; Traphagan et al., 2010). It was stated that if instructors support autonomy, by changing the curriculum and assessment and effectively interacting with students, learners are likely to value the task and experience positive feelings related to courses (Gelles et al., 2020). Hence, they are more likely to show behavioral and cognitive engagement considerably (Assor et al., 2002). It can be seen that the presence of teachers might also be related to perceived cognitive presence, which should be investigated in teacher training distance education classes.

According to Figure 1, the personal relevancy dimension of the distance education learning environment is related to the cognitive presence, which is about relating the content of the course with the personal experiences of learners. Also, it is about applying what has been learned in courses outside of the classroom to the lives of learners (Aldridge et al., 2013) and was stated as 
one of the most vital determinants of course satisfaction (Ke \& Kwak, 2013). This property is related reasonably to the active and authentic learning properties of the distance education classroom environment. Authentic learning requires course designers to include real-life experiences, including ill-defined problems, investigation for an extended period using multiple sources and perspectives, collaboration, reflection, interdisciplinary perspective, an integrated assessment, which is not merely summative but is woven into the tasks in the learning process (Herrington et al., 2004; Huang, 2002; Reeves et al., 2002; Roman, et al., 2020). It can be inferred that personal relevancy and authentic learning are related to active learning as it involves students' calculating, discussing, creating, solving real-life problems, connecting concepts, etc. which is different from being passive receivers of knowledge (Lombardi, 2007) and leads to positive results in terms of student outcomes (Puzziferro \& Shelton, 2008). By taking part in learning tasks actively, learners feel that they are being accepted, valued, and guided during discussions, and evaluate the distance education learning environments positively, which also contribute to the social presence.

Long et al. (2021) looked at how students' views of learning settings changed before and after moving to remote teaching. Students reported a statistically significant decrease in student cohesion, instructor support, involvement, and task orientation characteristics, which should be investigated in Turkish teacher education settings. Arrk (2021) discovered that university students were undecided about distance education learning environments, i.e., whether they were qualified or not, in terms of providing teacher support, enabling student interaction and collaboration, addressing personal relevance, supporting authentic, active learning, student autonomy, and providing a favourable community. As the proper distance education environment perceptions lead to better student outcomes such as achievement, learning motivation, confidence in solving questions and attitudes (Bian et al. 2018; Fraser, 1998), the inclusion of various variables at the same study and viewing the distance education teacher training environments with a finer lens is one of the difference and the significance of this study. Moreover, by understanding distance education learning environments and the online community, instructors and course designers can benefit from findings while designing distance education courses after the post pandemic period. Also, through this research, how these distance education environment variables impacted perceived $\mathrm{CoI}$ in distance teacher education learning environments is revealed and it is hoped that the research contributes to the overall literature on distance teacher education learning environments and the CoI model.

Moreover, it was stated that gender inequalities yielded a diverse range of results in distance learning environments (Ashong \& Commander, 2012; Cai, Fan \& Du, 2017; Korlat et al., 2021; Lau et al., 2020; Nistor, 2013; Yu, 2021). Males had higher favorable attitudes regarding technology use than females, according to Cai et al. (2017). While female graduate students in Psychology and Educational Sciences had more consistent engagement, male students had more steady positive attitudes regarding distance learning (Nistor, 2013). Furthermore, females demonstrated stronger self-regulation and confidence in their metacognitive abilities in distance learning contexts, used several strategies to manage their learning, and completed tasks successfully (Alghamdi et al., 2020). Males could use more learning strategies and have better technical skills than females. Girls had stronger perceived teacher support and learning engagement than boys, according to Korlat et al. (2021), although there were no significant gender differences in digital learning competency beliefs among Austrian secondary school students. Furthermore, Ashong and Commander (2012) found that females have more positive attitudes toward online learning than males, particularly in terms of teacher support, student interaction and collaboration, personal relevance, authentic learning, and student autonomy. On the other hand, Yu (2021) discovered that gender had no significant influence on the outcomes of undergraduate and postgraduate students. Furthermore, Lau et al. (2020) found no significant variations in CoI dimensions between male and female engineering and business students. As can be seen, the impact of gender on distance learning contexts is debatable, necessitating further research in teacher education settings. 
Furthermore, there has been little research into how learners' departments affect instructional outcomes in distance education learning contexts (Rizvia et al., 2019). The levels of students' perceived social, cognitive, and teaching presence were found to be insignificant among participants from soft-pure, soft-applied, hard-pure, and hard-applied disciplinary areas, according to Lim and Richardson (2020); however, teaching presence was perceived to be the highest, followed by cognitive and social presence. Students mostly tend to consider social presence as being less important than cognitive and teaching presence. In Israel's Open University course forums, Gorsky et al. (2010) discovered that active participation of learners in submitting posts in science forums was substantially higher than in humanities forums. The humanities forum had a higher level of social presence, whereas the science forum had a higher level of cognitive presence. According to Arbaugh et al. (2010), students in education, who were followed by students in the health department, had greater cognitive presence scores than students in pure disciplines such as physics, mathematics, and social studies. Previous studies have shown that departmental distinctions can have a major impact on students' perceptions of distance education learning environments necessitating more research from a broader range of academic disciplines.

This study aimed to reveal the perceptions of pre-service teachers about distance education learning environment variables (instructor support, student interaction and collaboration, personal relevance, authentic learning, active learning, and student autonomy) and Community of Inquiry variables (teaching, social and cognitive presence) and clarify the relations between these two sets. In terms of the aim of the study, the following research questions were sought:

1. Are there gender differences in the Distance Education Learning Environment and Community of Inquiry perceptions of pre-service teachers?

2. Are there departmental differences in the Distance Education Learning Environment and Community of Inquiry perceptions of pre-service teachers?

3. What is the relationship between Distance Education Learning Environment Variables and Community of Inquiry Variables perceived by pre-service teachers?

\section{Method}

\subsection{Research Design}

A relational survey research design was adopted for the study as it aimed to reveal the current perceptions of pre-service teachers about distance education teacher training learning environments and community of inquiry and the degree of relationships between these two variables sets (Cohen et al., 2007; Fraenkel \& Wallen, 2009).

\subsection{Sample}

This study included volunteer first, second, and third year pre-service teachers enrolled at a state university in Turkey in the 2020-2021 education year. All the pre-service teachers who participated in the research took distance education courses for at least one semester. Although pre-service teachers were expected to continue synchronous courses weekly; however, there were no obligations. As the seniors did not attend to synchronous courses regularly, but listened to the subjects from live course records, they might not reflect the distance education learning environments thoroughly. For this reason, they were not included in the study. In this study, cross-sectional data were collected from 262 volunteer pre-service teachers and, among them, 195 $(74.4 \%)$ were female and $67(25.6 \%)$ were male. The distribution of pre-service teachers across their departments can be seen in Table 1.

\subsection{Instruments}

In this study, the Community of Inquiry (CoI) Inventory and the Distance Education Learning Environment Survey (DELES) were implemented to collect data. The Distance Education Learning Environment Survey (DELES) was developed by Walker and Fraser (2005) and includes six 
Table 1

The distribution of pre-service teachers according to their departments

\begin{tabular}{lcc}
\hline Departments & $f$ & $\%$ \\
\hline Classroom Teaching & 44 & 16.8 \\
Elementary School Mathematics Teaching & 24 & 9.2 \\
Guidance and Psychological Counselling & 56 & 21.4 \\
Science and Technology Teaching & 31 & 11.8 \\
Social Sciences Teaching & 45 & 17.2 \\
Turkish Language Teaching & 62 & 23.7 \\
\hline Total & 262 & 100 \\
\hline
\end{tabular}

psychosocial scales ('Instructor Support', 'Student Interaction and Collaboration', 'Personal Relevance', 'Authentic Learning', 'Active Learning' and 'Learner Autonomy') with 34 items. The alpha reliability coefficient of the DELES scales ranged from .75 to .95 (Walker \& Fraser, 2005). The DELES was adapted to the Turkish higher education context by Ozkok et al. (2009) with 595 postsecondary students in 2005-2006. The number of items, sample items and reliability coefficient for each scale were shown in Appendix 1. Cronbach's alpha coefficient for each adapted scale ranged from .64 to .84 , with an overall reliability estimate of .93 for 34-items. For the current study, Cronbach's alpha coefficient for each scale ranged from .62 to .90 .

Arbaugh et al. (2008) developed the CoI Inventory, which was adapted into Turkish by Ozturk (2012). The inventory's validity and reliability were tested with 140 Computer Education and Instructional Technology Teaching students who had prior online or blended learning experience. The CoI inventory is composed of three factors with 34 items. In this study, the factor structure of the CoI was confirmed through Confirmatory Factor Analysis (CFA). The CFA was conducted using Lisrel 8.7. In the current data set, CFA proposed the following model fit indices: $\chi^{2}(d f=552)=1381.94, p<.000$. The value of $\chi^{2} / d f=2.50(p<.000)$ is less than 3 which indicates good fitting statistics (Hair et al., 2014). Since it was significant, other goodness of fit indices were checked. Root Mean Square Error of Approximation-RMSEA = .079, Comparative Fit Index-CFI= .95, Normed Fit Index-NFI= .93, Non-Normed Fit Index-NNFI= .95, Incremental Fit Index-IFI $=.95$, and Relative Fit Index-RFI= .93, which showed acceptable values for the model fit indices as they are 90 (Hair et al., 2014; Tabachnick \& Fidell, 2007). The reliability coefficient for teaching presence is $\alpha=93$; social presence $\alpha=84$; cognitive presence $\alpha=91$.

\subsection{Data Collection Procedures}

After obtaining necessary permissions, scales were implemented to volunteer pre-service teachers enrolled at a state university in Turkey in the 2020-2021 education year. Before the implementation of scales, pre-service teachers were informed about the purpose of the study and the fact that their information would only be used for research purposes by the researcher and their answers would be kept confidential. They had the right to withdraw from the study at any time they wanted. The researcher was available online during the implementation of scales to answer any possible questions. The administration of the instruments was conducted online and took approximately 25 minutes.

\subsection{Data Analysis}

In order to answer the first and second research questions and investigate the effects of gender and department, on DELES and CoI variables separate Multivariate Analysis of Variance (MANOVA) was conducted after checking the assumptions (Tabachnick \& Fidell, 2007). In this sense, univariate and multivariate normality, homogeneity of variances and homogeneity of the covariance assumptions were checked (Tabachnick \& Fidell, 2007). The skewness and kurtosis values were between -1 and +1 (Field, 2009) and the Levene's test for homogeneity of variances was not significant. Also, the Box's M test was checked for homogeneity of the covariance 
assumption and reported. The statistical significance level was set at .05 . Moreover, before interpreting univariate analysis, Bonferroni correction was conducted by dividing the alpha value by the number of dependent variables $(.05 / 9=.0044)$ in order to keep strict type 1 error control (Field, 2009; Hair et al., 2014).

In this study, simple correlations were evaluated according to Cohen (1988) criteria. In terms of magnitude of effect sizes, correlation coefficients in the order of .10 are 'small', those of .30 are 'medium', and those of .50 are 'large'. In addition, Canonical Correlation was performed to investigate the relationship between the DELES variables and CoI variables. The purpose of canonical correlation analysis is to examine the relationships between two variable sets consisting of more than one variable and reveal to what extent the independent variable set can explain the dependent variable set (Tabachnick \& Fidell, 2007). In other words, numerous dependent variables are predicted from various independent variables (Hair et al., 2014). Therefore, canonical correlation analysis prevents the increase in type I error (Tabachnick \& Fidell, 2007).

The assumptions of canonical correlation were checked and reported before the study. The assumption of multicollinearity was checked in this study. In this context, the variables should not be too correlated with each other. Checking the simple correlations, none of the correlations were above .90 (Tabachnick \& Fidell, 2007). Also, the variance inflation factor (VIF) values were less than 10 and the tolerance values were greater than 0.2. It has been determined that there is no multi-collinearity problem (Field, 2009).

According to Hair (et al., 2014), small sample sizes may obscure any meaningful relationship; hence, there should be at least 10 observations per variable (Hair et al., 2014; Tabachnick \& Fidell, 2007). Since there are nine variables, the sample size $(n=262)$ is adequate for this study. Moreover, the absence of outliers, and linearity assumptions of canonical correlation were checked. While checking for the assumption of multivariate normality, it was seen that this assumption was violated according to Mardia's test. However, as stated by Hair (et al., 2014), if the sample size is large, the impact of non-normality might be negligible. After checking the assumptions, significant canonical variates, canonical loadings, and the redundancy indices were explained. While deciding the number of reliable canonical variate pairs in the data set, canonical correlations greater than .30 were interpreted (Hair et al., 2014).

\section{Results}

Before answering research questions, descriptive results about the perceptions of pre-service teachers about DELES variables according to gender and department were presented in Table 2.

Table 2

Mean scores and standard deviations of DELES variables in terms of gender and department

\begin{tabular}{|c|c|c|c|c|c|c|c|c|c|c|c|c|}
\hline \multirow[t]{2}{*}{ Group ${ }^{*}$} & \multicolumn{2}{|c|}{$\begin{array}{l}\text { Instructor } \\
\text { support }\end{array}$} & \multicolumn{2}{|c|}{$\begin{array}{c}\text { Student } \\
\text { Interaction and } \\
\text { Collaboration }\end{array}$} & \multicolumn{2}{|c|}{$\begin{array}{l}\text { Personal } \\
\text { Relevancy }\end{array}$} & \multicolumn{2}{|c|}{$\begin{array}{l}\text { Authentic } \\
\text { Learning }\end{array}$} & \multicolumn{2}{|c|}{$\begin{array}{c}\text { Active } \\
\text { Learning }\end{array}$} & \multicolumn{2}{|c|}{$\begin{array}{c}\text { Student } \\
\text { Autonomy }\end{array}$} \\
\hline & $\mathrm{M}$ & SD & $\mathrm{M}$ & SD & $\mathrm{M}$ & SD & $\mathrm{M}$ & SD & $\mathrm{M}$ & SD & $\mathrm{M}$ & SD \\
\hline Female & 4.53 & .48 & 3.31 & .94 & 4.12 & .88 & 3.89 & .58 & 4.18 & .48 & 4.31 & .51 \\
\hline Male & 4.35 & .61 & 3.47 & .95 & 4.06 & .58 & 3.83 & .73 & .16 & .57 & 4.21 & .51 \\
\hline Class & 4.46 & .49 & 3.29 & 1.02 & 4.23 & .5 & & .62 & 4.31 & .44 & 4.29 & .54 \\
\hline Math & 4.52 & .49 & 3.31 & .87 & 3.88 & .61 & 3.79 & .57 & 3.89 & .49 & 4.19 & .47 \\
\hline PDR & 4.48 & .42 & 3.05 & .99 & 4.07 & .53 & 3.80 & .62 & 4.17 & .46 & 4.21 & .54 \\
\hline Science & 4.52 & .47 & 3.65 & .84 & 4.10 & .60 & 4.01 & .51 & 4.16 & .48 & 4.32 & .56 \\
\hline Social & 4.46 & .62 & 3.23 & .89 & 4.11 & .54 & 3.88 & .54 & 4.22 & .52 & 4.36 & .43 \\
\hline Turkish & 4.48 & .60 & 3.61 & .89 & 4.12 & .66 & 3.86 & .76 & 4.16 & .58 & 4.32 & .51 \\
\hline
\end{tabular}

Note: * PDR-Guidance and Psychological Counselling; Math-Elementary School Mathematics Teaching; ClassElementary Education Classroom Teaching; Turkish-Turkish Language Teaching; Social-Social Sciences Teaching; Science-Science and Technology Teaching. 
According to the results of descriptive statistics as shown in Table 2, female and male preservice teachers perceived the distance education classroom environment almost at similar levels, while females obtained slightly higher mean scores than males according to all dimensions of the distance education environment except student interaction and collaboration. Also, pre-service teachers perceived the classroom environment at almost similar levels according to their departments. The pre-service teachers who were in elementary school mathematics teaching $(M=4.52, S D=.49)$ and Science and Technology Teaching $(M=4.52, S D=.47)$ departments perceived instructor support higher than those in other departments. Also, pre-service teachers who were in science and technology teaching department perceived student interaction and collaboration $M=3.65(S D=.84)$ and authentic learning dimensions $M=4.01(S D=.51)$ higher than other departments. The personal relevancy $M=4.23(S D=.53)$ dimension was perceived higher by the classroom teaching department than by other departments. Finally, pre-service teachers who were in Social Sciences Teaching departments perceived student autonomy $M=4.36$ $(S D=.43)$ higher than other departments, which was followed by Turkish Language Teaching $M=4.32(S D=.51)$ and Science and Technology Teaching $M=4.32(S D=.56)$ departments.

The descriptive results about the perceptions of pre-service teachers about CoI variables according to gender and department were presented in Table 3.

Table 3

Mean scores and standard deviations of CoI variables in terms of gender and department

\begin{tabular}{lcccccc}
\hline Group $^{*}$ & \multicolumn{2}{c}{ Teaching Presence } & \multicolumn{2}{c}{ Social Presence } & \multicolumn{2}{c}{ Cognitive Presence } \\
\cline { 2 - 7 } Female & $\mathrm{M}$ & $\mathrm{SD}$ & $\mathrm{M}$ & $\mathrm{SD}$ & $\mathrm{M}$ & SD \\
Male & 4.46 & .47 & 3.50 & .65 & 4.13 & .54 \\
Classroom & 4.16 & .54 & 3.46 & .64 & 3.92 & .47 \\
Math & 4.37 & .45 & 3.43 & .41 & 4.00 & .53 \\
PDR & 4.27 & .56 & 3.35 & .46 & 4.17 & .58 \\
Science & 4.34 & .56 & 3.35 & .45 & 4.00 & .58 \\
Social & 4.42 & .43 & 3.54 & .49 & 4.09 & .52 \\
Turkish & 4.32 & .53 & 3.53 & .34 & 4.02 & .42 \\
\hline
\end{tabular}

Note: * PDR-Guidance and Psychological Counselling; Math-Elementary School Mathematics Teaching; ClassElementary Education Classroom Teaching; Turkish-Turkish Language Teaching; Social-Social Sciences Teaching; Science-Science and Technology Teaching

Descriptive statistics as demonstrated in Table 3 shows that female pre-service teachers perceived the CoI dimensions a little higher than males. Also, the community of inquiry perceptions of pre-service teachers did not differ much according to their departments. The preservice teachers who were in Turkish-Turkish Language Teaching department perceived teaching presence $M=4.50(S D=.49)$, social presence $M=3.64(S D=.49)$ and cognitive presence $M=4.20$ $(S D=.55)$ dimensions higher than in other departments.

In order to answer the first research question and investigate whether there were gender differences among the perceptions of pre-service teachers according to DELES and CoI variables, MANOVA was conducted. According to the MANOVA results, the value of Box's $M=83.31$ and $F(45,53421.70)=1.75, p=.00$. Since this test is significant, Pillai's Trace test results were interpreted (Hair et. al., 2014). Pillai's Trace test was significant (Pillai's Trace $=.10$ ) and gender had a significant effect on dependent variables $F(9,252)=3.25, p<.00$. 
Table 4

Multivariate and univariate analyses of DELES and CoI variables in terms of gender

MANOVA ANOVA

$F(9,252)$

$F(1,260)$

\begin{tabular}{|c|c|c|c|c|c|c|c|c|c|c|}
\hline 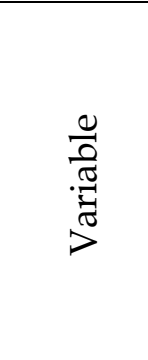 & & 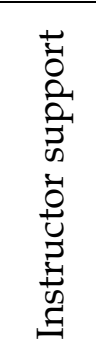 & 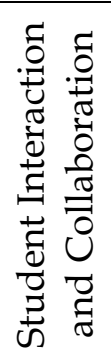 & 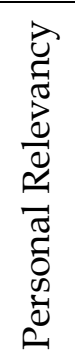 & 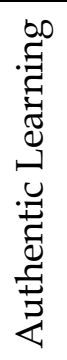 & 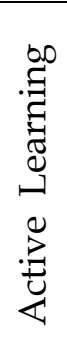 & 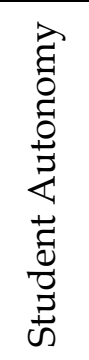 & 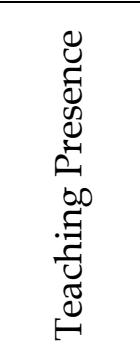 & 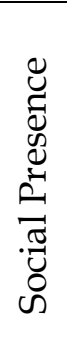 & 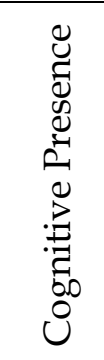 \\
\hline Gender & $3.25^{*}$ & 6.19 & 1.52 & .43 & .47 & .04 & 2.15 & $18.78^{* *}$ & .15 & $8.33^{* *}$ \\
\hline
\end{tabular}

After checking the multivariate results of MANOVA, univariate analyses were also interpreted after conducting Bonferroni correction by dividing the alpha value by the number of dependent variables $(.05 / 9=.0044)$ to hold tight Type I error control. According to separate univariate ANOVAs on the DELES and CoI variables, it was seen that gender had significant effects on both teaching and cognitive presence as shown in Table 4 . In other words, female pre-service teachers had significantly higher teaching presence scores $F(1,260)=18.78, p<.0044$ and cognitive presence scores $F(1,260)=8.33, p<.0044$ than males.

In order to answer the second research question and investigate whether there were departmental differences among the perceptions of pre-service teachers according to DELES and CoI variables, MANOVA was conducted. MANOVA revealed the value of Box's $M=323.43$ and $F(225,51940.52)=1.29, p=.00$. Pillai's Trace test results were interpreted (Hair et. al., 2014). Using Pillai's trace (Pillai's Trace $=.27$ ), there was a significant effect of department on the DELES and CoI variables together $F(45,1260)=1.59, p<.00$. However, separate univariate ANOVAs on the DELES and CoI variables revealed a non-significant effect of the department after conducting Bonferroni correction. In other words, being in any department had no significant effect on pre-service teachers' perception of each distance education classroom environment dimensions: instructor support $F(5,256)=.09, p=.99$; student interaction and collaboration $F(5,256)=3.04 p=.01$; personal relevancy $\mathrm{F}(5,256)=1.20, p=.31$; authentic learning $F(5,256)=.57, p=.72$; active learning $\mathrm{F}(5,256)=2.30, p=.05$; student autonomy $F(5,256),=.69, \quad p=.63$ and community of inquiry variables: teaching presence $F(5,256)=1.15, p=.34$; social presence $F(5,256)=1.61, p=.16$; cognitive presence $F(5,256)=1.38, p=.23$. The multivariate and univariate analyses for DELES and CoI variables in terms of the department were shown in Table 5.

Table 5

Multivariate and univariate analyses of DELES and CoI variables in terms of department

$\begin{array}{ll}M A N O V A & \text { ANOVA } \\ F(45,1260) & F(5,256)\end{array}$

\begin{tabular}{|c|c|c|c|c|c|c|c|c|c|c|}
\hline $\begin{array}{l}\frac{0}{0} \\
\frac{\pi}{\pi} \\
\text { ते } \\
>\end{array}$ & & 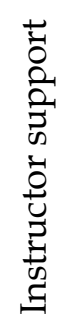 & 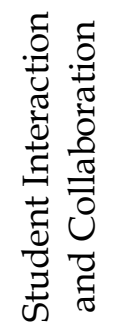 & 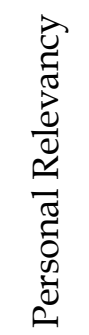 & 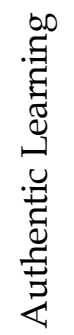 & 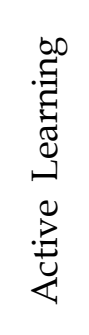 & 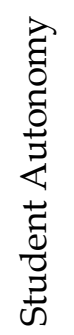 & 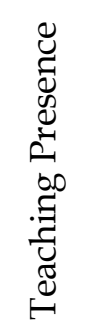 & 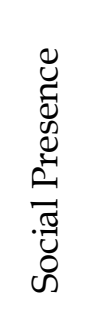 & 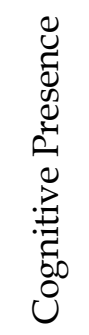 \\
\hline Department & $1.59^{*}$ & .09 & 3.04 & 1.20 & .57 & 2.30 & .69 & 1.15 & 1.61 & 1.38 \\
\hline
\end{tabular}

Note. ${ }^{*} p<.05$. 
In order to answer the third research question, canonical correlation analysis was conducted. First of all, simple correlations were revealed. According to Table 6, the highest correlation $(r=.66)$ was both between personal relevancy and authentic learning of the distance education classroom environment and teaching and cognitive presence dimensions of CoI. It can be inferred that as pre-service teachers perceived the instruction as personally relevant, they thought that it is authentic in this distance education teacher training classroom environment. It can be seen that the perceived relevancy of instruction $(r=.52)$ and perceived authentic learning $(r=.51)$ were related to cognitive presence. Also, instructor support through the design of proper instruction, motivating pre-service teachers, providing feedback, correcting misconceptions, etc. is related to the cognitive presence $(r=.52)$ and teaching presence $(r=.65)$. In addition, as pre-service teachers perceived the teaching presence $(r=.66)$ high, they also perceived the cognitive presence higher. Moreover, the student interaction and collaboration dimension is related to the perceived social presence $(r=.44)$, the perceived social presence is related to the perceived teaching presence dimension $(r=.46)$.

Table 6

Correlations among DELES and CoI Variables

\begin{tabular}{lccccccccc}
\hline & $(1)$ & $(2)$ & $(3)$ & $(4)$ & $(5)$ & $(6)$ & $(7)$ & $(8)$ & $(9)$ \\
\hline Instructor Support (1) & 1 & & & & & & & & \\
Student Interaction and & $.20^{* *}$ & 1 & & & & & & & \\
Collaboration (2) & & & & & & & & & \\
Personal Relevancy (3) & $.35^{* *}$ & $.39^{* *}$ & 1 & & & & & & \\
Authentic Learning (4) & $.24^{* *}$ & $.43^{* *}$ & $.66^{* *}$ & 1 & & & & & \\
Active Learning (5) & $.22^{* *}$ & $.14^{*}$ & $.38^{* *}$ & $.37^{* *}$ & 1 & & & & \\
Student Autonomy (6) & $.30^{* *}$ & .11 & $.35^{* *}$ & $.31^{* *}$ & $.63^{* *}$ & 1 & & & \\
Teaching Presence (7) & $.65^{* *}$ & $.26^{* *}$ & $.38^{* *}$ & $.39^{* *}$ & $.26^{* *}$ & $.33^{* *}$ & 1 & & \\
Social Presence (8) & $.37^{* *}$ & $.44^{* *}$ & $.33^{* *}$ & $.39^{* *}$ & $.18^{* *}$ & $.20^{* *}$ & $.46^{* *}$ & 1 & \\
Cognitive Presence (9) & $.52^{* *}$ & $.39^{* *}$ & $.52^{* *}$ & $.51^{* *}$ & $.28^{* *}$ & $.35^{* *}$ & $.66^{* *}$ & $.60^{* *}$ & 1 \\
\hline
\end{tabular}

Note. ${ }^{*} \mathrm{p}<.05,{ }^{* *} \mathrm{p}<.01$

In this study, there are six variables for the first set of variables and there are three variables for the second set of variables. Since there are three levels of the second set, this analysis yielded three variate pairs within the canonical structure. In this study, as shown in Table 7, only the first two functions were found meaningful, i.e. canonical correlation was greater than .30. The first solution's correlation loading value was meaningful, $r_{c}=.75$ (56\% overlapping variance). Also, Wilk's test results were checked to see if the models were significant or not. Accordingly, it was obtained that the first model was significant, Wilks's $\lambda=0.37, F(18,718)=16.98, p<.00$. The second model was also meaningful, $r_{c}=.33$ (10.9\% overlapping variance) and in Wilk's test results, Wilks's $\lambda=0.85, F(10,510)=4.47, p<.00$.

As the canonical loadings greater than .30 were determined as meaningful correlations (Hair et. al., 2014) presented in Table 7, concerning the first canonical function, the variables "instructor support $\left(r_{c}=-.85\right)$ ", "student interaction and collaboration $\left(r_{c}=-.52\right)$ ", "personal relevance" $\left(r_{c}=-.65\right)$, "authentic learning $\left(r_{c}=-.66\right)$ ", "active learning $\left(r_{c}=-.39\right)$ ", "student autonomy $\left(r_{c}=-.48\right)$ " in the "Distance Education Learning Environments" set was significantly correlated with the variables "teaching presence $\left(r_{c}=-.90\right)$ ", "social presence $\left(r_{c}=-.68\right)$ " and "cognitive presence $\left(r_{c}=-.90\right)$ " in the Community of Inquiry variable set. 
Table 7

Correlations and standardized canonical coefficients, percentages of variance and redundancies between DELES variables and CoI variables

\begin{tabular}{|c|c|c|c|c|}
\hline & \multicolumn{2}{|c|}{ First variate } & \multicolumn{2}{|c|}{ Second variate } \\
\hline & $\begin{array}{l}\text { Canonical } \\
\text { Loadings }\end{array}$ & $\begin{array}{c}\text { Canonical } \\
\text { Correlation } \\
\text { coefficient }\end{array}$ & $\begin{array}{l}\text { Canonical } \\
\text { Loadings }\end{array}$ & $\begin{array}{c}\text { Canonical } \\
\text { Correlation } \\
\text { coefficient }\end{array}$ \\
\hline \multicolumn{5}{|l|}{ DELES variables } \\
\hline Instructor support & $-.85^{*}$ & -.66 & $.46^{*}$ & .68 \\
\hline $\begin{array}{l}\text { Student interaction/ } \\
\text { collaboration }\end{array}$ & $-.52^{*}$ & -.20 & $-.77^{*}$ & -.76 \\
\hline Personal relevance & $-.65^{*}$ & -.09 & $-.30^{*}$ & -.14 \\
\hline Authentic learning & $-.66^{*}$ & -.32 & $-.42 *$ & -.17 \\
\hline Active learning & $-.39 *$ & .04 & -.02 & .04 \\
\hline Student autonomy & $-.48^{*}$ & -.16 & .05 & .01 \\
\hline Percent of variance & .37 & & .17 & \\
\hline Redundancy & .21 & & .02 & \\
\hline \multicolumn{5}{|l|}{ Community of Inquiry variables } \\
\hline Teaching Presence & $-.90^{*}$ & -.53 & $.41^{*}$ & 1.09 \\
\hline Social Presence & $-.68^{*}$ & -.17 & $-.57^{*}$ & -.75 \\
\hline Cognitive Presence & $-.90^{*}$ & -.45 & -.26 & -.52 \\
\hline Percent of variance & .70 & & .18 & \\
\hline Redundancy & .40 & & .02 & \\
\hline Canonical Correlation & .75 & & .33 & \\
\hline
\end{tabular}

Note. *Meaningful correlations over .30.

As for the correlations of the variables in the second solution, the variables instructor support $\left(r_{c}=.46\right)$, student interaction collaboration $\left(r_{c}=-.77\right)$, personal relevance $\left(r_{c}=-.30\right)$, authentic learning $\left(r_{c}=-.42\right)$ in Distance Education Learning Environments set were significantly correlated with the variables teaching presence $\left(r_{c}=.41\right)$ and social presence $\left(r_{c}=-.57\right)$ in the Community of Inquiry variables set. However, the variable cognitive presence $\left(r_{c}=-.26\right)$ was not meaningfully correlated with any of the Distance Education Learning Environments variables. Also, the variables active learning $\left(r_{c}=-.02\right)$, student autonomy $\left(r_{c}=-.05\right)$ were not meaningfully related to any Community of Inquiry variables meaningfully in the second solution.

In terms of the percentage of the variance explained; in the first solution, $37 \%$ of the variance in "Distance Education Learning Environments" set was explained by its own canonical variables, while $21 \%$ of the variance in the Community of Inquiry Framework set was explained by the Distance Education Learning Environments set as well. Again, in the first solution, $70 \%$ of the variance in the Community of Inquiry Framework set was explained by its own canonical variables, while $.40 \%$ of the variance in the "Distance Education Learning Environments" set (opposite set) was accounted for by the "Community of Inquiry" variables.

In the second solution, $17 \%$ of the variance in the Distance Education Learning Environments set was explained by its own canonical variables, while $2 \%$ of the variance in the opposite set was accounted for by the DELES variables. Again, in the second solution model, $18 \%$ of the variance in the Community of Inquiry set was explained by its own canonical variables and $2 \%$ of the variance in the opposite (DELES variables) set was accounted for by the canonical variables of the CoI set.

\section{Discussion}

In this study, pre-service teachers' perceptions of distance education learning environment and community of inquiry variables, as well as the relationships between these variables, were investigated. Female pre-service teachers exhibited considerably greater teaching presence and 
cognitive presence scores than males in the current study. In a study similar to this one, Lim and Richardson (2020) showed that while teaching presence was perceived as the highest, all students tended to evaluate social presence as less than cognitive and teaching presence. In the study conducted by Long et al. (2021), teaching faculty students also mentioned the difficulty of completing group work and communicating with others during the pandemic. Furthermore, according to Louder (2011), undergraduate and graduate students placed less emphasis on active, authentic learning, engagement, and collaboration in distance education environments. It may be argued that in these distance teacher education contexts, student engagement and collaboration, which lead to social presence, were insufficient by corroborating the literature (Ferri et al., 2020; Lim \& Richardson, 2020). According to previous studies, females were shown to be more communication-oriented in an online setting, wanting engagement with others (Tsai \& Tsai, 2010); however, female pre-service teachers in the current study rated the teaching presence and cognitive presence dimensions of distance education learning environments significantly higher. Similar to the current study, females had more positive perceptions of online learning than males, according to Ashong and Commander (2012), particularly in terms of teacher assistance, student interaction and collaboration, personal relevance, authentic learning, and student autonomy. In other words, females were more positive about their instructors assisting them when they needed it, providing timely feedback, designing personally relevant and authentic activities, making connections with real-life experiences, participating in tasks and discussions to solve real-world problems, initiate ideas, and make their own decisions.

In this study, there were no significant differences in pre-service teachers' perceptions of distance teacher education learning environments and the CoI based on their departments, which corroborates the literature (Lau et al., 2020; Lim \& Richardson, 2020). By contradicting the findings of the study, according to Arbaugh et al. (2010), those in soft-applied disciplines (such as allied health and education) have greater cognitive presence scores than students in pure disciplines (such as mathematics, science, and social studies). Higher positive perceptions of pre-service teachers in science teaching department albeit it is not significant, may be connected with the nature of the discipline, similar to the finding of Gorsky et al. (2010). Many actual real-life problems and authentic activities are included in science courses, which necessitate teacher assistance and peer interaction to complete assignments based on problem-solving through interpersonal student-instructor and student-student interactions as also stressed in the study conducted by Roman et al. (2020). On the other hand, Social Sciences Teaching departments perceived student autonomy higher than other departments, as also revealed by Gorsky et al. (2010), since the evaluation in humanities courses commonly did not require tasks that were dependent on problem solving and the assistance of an instructor or peers intensively, as it does in science subjects. Moreover, Gorsky et al. (2010) investigated the levels of CoI in discussion boards. However, in the current study, the overall perceptions of pre-service teachers' DELES and CoI perceptions were investigated. The variations in results could be due to differences in the disciplinary areas and intended learning activities as also stated by Lim and Richardson (2020).

This study revealed that pre-service teachers obtained the highest score for instructor support, which was followed by the student autonomy dimension and the lowest score at the student interaction and collaboration dimension. In other words, while instructor support had a stronger influence on pre-service teachers in this distance teacher education community, student interaction and collaboration dimension had a weak influence. Furthermore, they rated teaching presence as the highest, while social presence was rated as the lowest. This finding corroborates Mullen and Tallent-Runnels (2006) that college students engaged in the self-directed learning process to a higher extent and did not rank interaction with peers and active learning as the preferred method for learning in distance education classes. It can be inferred that perceived instructor support due to the design of instruction, organization of learning activities, online discussions, and direct instruction in the distance learning environments resulted in higher levels. Instructor support, according to Aldridge et al. (2013), promotes learners to be courageous and confident in tackling 
new challenges, taking risks in their learning, and working on and completing tough tasks, which in turn related to the learner autonomy dimension of distant learning. In other words, teaching presence assisted learners in accomplishing personally relevant, meaningful and authentic educational tasks, which also back up the literature (Anderson et al., 2001; Roman et al., 2020; Snodin, 2013).

As revealed in the first canonical solution, the DELES variables were positively correlated with the Community of Inquiry variable set. In other words, as the level of perceived CoI increased, pre-service teachers perceived the distance teacher education learning environments positively. Also, teaching presence was found a core factor in determining learning outcomes which corroborates the literature (Garrison \& Arbaugh, 2007; Mullen \& Tallent-Runnels, 2006; Wu et al., 2017). The reason for this result could be that instructors contributed to distance teacher training learning environments positively by providing instant feedback, necessary corrections in online synchronous and asynchronous discussions, summarizing common themes, clarifying misconceptions and some conflicting ideas, and adding information from various sources which corroborates the literature (Arbaugh \& Hwang, 2006; Garrison et al., 2010; Shea et al, 2005; Shea et al., 2010; Traphagan et al., 2010). Similarly, Garrison and Kanuka (2004) stated that if online instruction is ineffective, one of the reasons might be the inappropriate design, insufficient facilitation, and support of the instructor. In addition, by corroborating the canonical solutions of the current study, according to Louder (2011), cognitive presence was influenced more by teacher support, personal relevance, and autonomy than by active and authentic learning, cooperation, and engagement. Smith (2000) discovered that student autonomy led to the development of skills, knowledge, and attitudes, allowing them to create knowledge with greater freedom. Also, Shea and Bidjerano (2009) revealed that $70 \%$ of the variance in the cognitive presence perceived by online students could be predicted based on instructor support and social presence.

Furthermore, the instructor support is positively related to the perceived social presence, which might have stemmed from the contribution of online course activities to student interaction and collaboration. Also, in this distance teacher education learning environment, perceived active learning was related to both social presence through student interaction, and collaboration and cognitive presence since pre-service teachers involved in various meaningful online tasks and discussions as also stated by Garrison and Akyol (2015). Similarly, Shea et al. (2010) explained that social presence improved as a function of instructor support and was found to mediate the development of cognitive presence. However, the current study revealed that after a level, as preservice teachers perceived higher teaching presence, they perceived less social presence and vice versa according to the second canonical solution.

According to the second solution, social presence was correlated with the teaching presence in a negative way. In other words, as instructor support increased in the second solution, teaching presence increased as well; however, as instructor support increased, social presence decreased. Furthermore, it was also revealed in the second solution that as the perceived student interaction and collaboration, personal relevance, and authentic learning increased, perceived social presence increased as well but teaching presence decreased. It might be inferred that as perceived instructor support increased, perceived teaching, social and cognitive presences increased to a certain level; however, intense instructor presence affected social presence negatively. The reason for this result might be that due to the intense presence of the instructor, and if the role of instructors was reflected mostly as knowledge transferor rather than being the facilitator of instruction as also stated by Carrillo and Flores (2020), pre-service teachers might perceive the interaction and collaboration among themselves less and the instruction heavily traditional, which in turn might have affected perceived personal relevance and authentic learning negatively, and decreased the perceived social presence as also stated by Roman et al. (2020). On the contrary, when learners perceived the interaction and collaboration among themselves as higher, the type of instruction being active, personally relevant, and authentic, they perceived increased social presence. It might be summarized that the perceived social and cognitive presence was related to mild instructor 
support, relevant instruction, authentic, active learning, student interaction and collaboration, and autonomy properties of the classroom environment.

\section{Conclusion and Limitations}

The study revealed that female pre-service teachers exhibited considerably greater teaching presence and cognitive presence scores than males. Also, there were no significant differences in pre-service teachers' perceptions of distance education learning environments and the CoI based on pre-service teachers' departments. In this study, pre-service teachers obtained the highest score for instructor support, which was followed by the student autonomy dimension and the lowest score at the student interaction and collaboration dimension. It can be stated that while instructor support had a stronger influence on pre-service teachers, the student interaction and collaboration dimension had a weak influence in this distance teacher education community. Moreover, among the $\mathrm{CoI}$ factors, perceived teaching presence was the highest, whereas social presence was the lowest. The findings of this study might provide useful data for teacher educators to design their curriculum and instruction for the post Covid-19 education and blended courses. In the present study, important results were achieved within some limitations.

First of all, this study was limited to the data obtained from first, second, and third year preservice teachers studying in six different departments of a state university in Turkey. Because preservice teachers studying at a private institution or taking graduate courses covering more advanced topics may have different perceptions, the findings of this study should be carefully extrapolated to other circumstances. Additional research should be conducted using data acquired from other contexts and people from diverse departments. In addition, participants from each department were disproportionate. For instance, in the Elementary School Mathematics Teaching department, only 24 pre-service teachers were volunteer to take part in the study, which might have affected the power of analysis. Hence, future research should collect proportionate data from different departments. Also, this study was limited to the data collected through DELES and CoI scales online since it was not possible to reach pre-service teachers face-to-face in this emergency situation or collect extensive qualitative data. The current study explored the pre-service teachers' perceptions of the distance education learning environment and $\mathrm{CoI}$ based on gender and department. Further research might investigate them according to different criteria, such as being a self-directed learner, competence beliefs in using technology, engagement, motivation, etc. Finally, in this study, the DELES and CoI scales were implemented at the end of the semester. However, as the distance education learning environment perception of pre-service teachers might change over time, further research might investigate them over time.

\section{Educational Implications}

According to the findings of the study, for effective instruction, pre-service teachers should be provided with strong instructor support by incorporating effective online course design, feedback on assignments, regular interactions between the faculty and pre-service teachers, and adequate and relevant responses to their questions about coursework and materials. The social presence dimension is weak in these distance education learning environments. It might be suggested that if teachers design online courses by including active learning opportunities such as peer learning sessions, group discussions and asynchronous forum discussions to improve interpersonal interactions, in this way, teaching presence through course design might increase the perceived cognitive and social presence.

This study revealed that personal relevance, authentic learning and student autonomy dimensions of distance education teacher training learning environments were significantly related to the dimensions of CoI. For this reason, it might be suggested that instruction should be designed as personally relevant and as authentic as possible, as well as support student autonomy by incorporating various opportunities for the same instructional goals, such as meaningful dialogues, case studies, role-playing exercises, collaborative group studies and internships. 
Moreover, instructors might provide flexible due dates, different alternatives for assessment, choice for learning tasks and assignments, and option to participate synchronous or asynchronous sections. Also, it might be suggested that instructors should consider the relevance of instruction, which is important to increase motivation, and engagement in academic activities, which in turn contribute to cognitive presence. In this regard, instructors should explain how learning tasks contribute to learners' personal goals, and incorporate real-world applications or examples so that the content discussed in class translates to the real world and allows learners to see how the subject matter relates into their lives outside of the classroom. Finally, because the study found that instructors play an important role in effective distance education courses, universities may organize training programs for instructors to improve their awareness and knowledge of how to use distance learning systems, such as course management systems or software relevant to their courses, which affect the effectiveness of distance learning environments and learner outcomes positively.

\section{References}

Abeysekera, L., \& Dawson, P. (2015). Motivation and cognitive load in the flipped classroom: Definition, rationale and a call for research. Higher Education Research $\mathcal{E}$ Development, 34(1), 1-14. https://doi.org/10.1080/07294360.2014.934336

Akyol, Z., Garrison, D. R., \& Ozden, M. Y. (2009). Online and blended communities of inquiry: Exploring the developmental and perceptional differences. The International Review of Research in Open and Distributed Learning, 10(6), 65. https://doi.org/10.19173/irrodl.v10i6.765

Aldridge, J. M., Afari, E., \& Fraser, B. J. (2013). Influence of teacher support and personal relevance on academic self-efficacy and enjoyment of mathematics lessons: A structural equation modeling approach. Alberta Journal of Educational Research, 58(4), 614-633.

Alghamdi, A., Karpinski, A. C., Lepp, A., \& Barkley, J. (2020). Online and face-to-face classroom multitasking and academic performance: Moderated mediation with self-efficacy for self-regulated learning and gender. Computers in Human Behavior, 102, 214-222. https://doi.org/10.1016/j.chb.2019.08.018

Almaiah, M. A., Al-Khasawneh, A. \& Althunibat, A. (2020). Exploring the critical challenges and factors influencing the e-learning system usage during Covid-19 pandemic. Education and Information Technologies, 25, 5261-5280. https://doi.org/10.1007/s10639-020-10219-y

Anderson, T., Rourke, L., Garrison, D. R., \& Archer, W. (2001). Assessing teaching presence in a computer conferencing context. Journal of Asenkronus Learning Network, 5(2), 1-17. https://doi.org/10.24059/olj.v5i2.1875

Arbaugh, J. B., Bangert, A., \& Cleveland-Innes, M. (2010). Subject matter effects and the Community of Inquiry (CoI) framework: An exploratory study. The Internet and Higher Education, 13(1-2), 37-44. https://doi.org/10.1016/j.iheduc.2009.10.006

Arbaugh, J. B. (2007). An empirical verification of the community of inquiry framework. Journal of Asynchronous Learning Networks, 11(1), 73-85.

Arbaugh, J. B., Cleveland-Innes, M., Diaz, S. R., Garrison, D. R., Ice, P., Richardson, J. C., \& Swan, K. P. (2008). Developing a community of inquiry instrument: Testing a measure of the Community of inquiry framework using a multi-institutional sample. The Internet and Higher Education, 11(3-4), 133-136. https://doi.org/10.1016/j.iheduc.2008.06.003

Arbaugh, J. B., \& Hwang, A. (2006). Does "teaching presence" exist in online MBA courses? The Internet and Higher Education, 9, 9-21. https:/ / doi.org/10.1016/j.iheduc.2005.12.001

Arık, S. (2021). Distance education learning environments during COVID-19 pandemic from student perspectives: A study in Turkish higher education. Journal of Pedagogical Research, 5(2), 103-118. http://dx.doi.org/10.33902/JPR.2021269494

Ashong, C. Y., \& Commander, N. E. (2012). Ethnicity, gender, and perceptions of online learning in higher education. MERLOT Journal of Online Learning and Teaching, 8(2), 1-17.

Assor, A. Kaplan, H. \& Roth, G. (2002). Choice is good, but relevance is excellent: Autonomy-enhancing and suppressing teacher behaviours predicting students' engagement in schoolwork. British Journal of Educational Psychology, 72, 261-278. https://doi.org/10.1348/000709902158883 
Bangert, A. W. (2009). Building a validity argument for the community of inquiry survey instrument. The Internet and Higher Education, 12(2), 104-111. https://doi.org/10.1016/j.iheduc.2009.06.001

Baran, E. \& Alzoubi, D. (2020). Human-centered design as a frame for transition to remote teaching during the Covid-19 pandemic. Journal of Technology and Teacher Education, 28(2), 365-372.

Bian, H., Bian, Y., Li, J., Li, Y., Ma, Y., Shao, X., \& Xu, J. (2018). Peer instruction in a physiology laboratory course in China. Advances in Physiology Education, 42, 449-453. https://doi.org/10.1152/advan.00153.2017

Cai, Z., Fan, X., \& Du, J. (2017). Gender and attitudes toward technology use: A meta-analysis. Computers $\mathcal{E}$ Education, 105, 1-13. http://dx.doi.org/10.1016/j.compedu.2016.11.003

Carlon, S., Bennett-Woods, D., Berg, B., Claywell, L., LeDuc, K., Marcisz, N., Mulhall, M., Noteboom, T., Snedden, T., Whalen, K., \& Zenoni, L. (2012). The community of inquiry instrument: Validation and results in online health care disciplines. Computers $\mathcal{E}$ Education, 59(2), 215221. https://doi.org/10.1016/j.compedu.2012.01.004

Carrillo, C., \& Flores, M. A. (2020). COVID-19 and teacher education: A literature review of online teaching and learning practices. European Journal of Teacher Education, 43(4), 466-487. https:// doi.org/10.1080/02619768.2020.1821184

Chou, S-W. \& Liu, C-H. (2005). Learning effectiveness in a web-based virtual learning environment: A learner control perspective. Journal of Computer Assisted Learning, 21(1), 65-76. https:// doi.org/10.1111/j.1365-2729.2005.00114.x

Cohen, J. (1988) Statistical power analysis for the behavioral sciences. Erlbaum.

Cohen, L., Manion, L. \& Morrison, K. (2007). Research methods in education. Routledge. https://doi.org/10.4324/9780203029053

Diaz, S. R., Swan, K., Ice, P., \& Kupczynski, L. (2010). Student ratings of the importance of survey items, multiplicative factor analysis, and the validity of the community of inquiry survey. Internet and Higher Education, 13(1-2), 22-30. https:// doi.org/10.1016/j.iheduc.2009.11.004

Ferri, F., Grifoni, P., \& Guzzo, T. (2020). Online learning and emergency remote teaching: Opportunities and challenges in emergency situations. Societies, 10(86), 1-18. https://doi.org/10.3390/soc10040086

Field, A. P. (2009). Discovering statistics using spss. (3 $3^{\text {th }}$ Ed.). Sage.

Fraenkel, J. R. \& Wallen, N. E. (2009). How to design and evaluate research in education (7th ed.). McGraw Hill.

Fraser, B. J. (1998). Classroom environment instruments: Development, validity, and applications. Learning Environments Research, 1(1), 7-33. https://doi.org/10.1023/A:1009932514731

Garrison, D. R. \& Akyol, Z. (2015). Thinking collaboratively in educational environments: Shared metacognition and co-regulation in communities of inquiry. In J. Lock, P. Redmond, P. A. Danager (Eds.) Educational Developments, Practices and Effectiveness (pp.39-52). Palgrave Macmillan. https://doi.org/10.1057/9781137469939_3

Garrison, D. R., Anderson, T., \& Archer, W. (2000). Critical inquiry in a text-based environment: Computer conferencing in higher education. The Internet and Higher Education, 2(2-3), 87-105. https://doi.org/10.1016/S1096-7516(00)00016-6

Garrison, D. R., \& Arbaugh, J. B. (2007). Researching the community of inquiry framework: Review, issues, and future directions. The Internet and Higher Education, 10(1), 157-172. https://doi.org/10.1016/j.iheduc.2007.04.001

Garrison, D. R., Cleveland-Innes, M., \& Fung, T. S. (2010). Exploring causal relationships among teaching, cognitive and social presence: Student perceptions of the community of inquiry framework. The Internet and Higher Education, 13(1), 31-36. https://doi.org/10.1016/j.iheduc.2009.10.002

Garrison, D., \& Kanuka, H. (2004). Blended learning: Uncovering its transformative potential in higher education. The Internet and Higher Education, 7(1), 95-105. https://doi.org/10.1016/j.iheduc.2004.02.001

Gelles, L. A., Lord, S. M., Hoople, G. D., Chen, D. A., \& Mejia, J. A. (2020). Compassionate Flexibility and Self-Discipline: Student Adaptation to Emergency Remote Teaching in an Integrated Engineering Energy Course during COVID-19. Education Sciences, 10(304), 1-23. https://doi.org/10.3390/educsci10110304

Gorsky, P., Caspi, A., Antonovsky, A., Blau, I. \& Mansur, A. (2010). The relationship between academic discipline and dialogic behavior in open university course forums. The International Review of Research in Open and Distributed Learning, 11(2), 49-72. https://doi.org/10.19173/irrodl.v11i2.820

Hair, J. F., Black, W. C., Babin, B. J., \& Anderson, R. E. (2014). Multivariate data analysis. Pearson New International Education.

Henderson, J., Willoughby, J. R., \& Flegle, J. (2009). A paragdigm for creating a sustainable learning and service community in an online university: Theory and practice. International Leadership Journal, 2(1), 7590. 
Herrington, J., Reeves, T. Oliver, R., \& Woo, Y. (2004). Designing authentic activities in web-based courses. Journal of Computing and Higher Education, 16(1), 3-29. https://doi.org/10.1007/BF02960280

Hodges, C., Moore, S., Lockee, B., Trust, T. \& Bond, A. (2020, March 13). The difference between emergency remote teaching and learning. EDUCAUSE Review. https:/ / er.educause.edu/articles/2020/3/the-difference-between-emergency-remoteteaching-and-online-learning

Huang, H. M. (2002). Towards constructivism for adult learners in online learning environments. British Journal of Educational Technology, 33(1), 27-37. https:/ / doi.org/10.1111/1467-8535.00236

Ke, F. \& Kwak, D. (2013). Constructs of student-centered online learning on learning satisfaction of a diverse online student body: A structural equation modeling approach. Journal of Educational Computing Research, 48(1) 97-122. https://doi.org/10.2190/EC.48.1.e

Knight, J. K. \& Brame, C. J. (2018). Peer Instruction. CBE-Life Sciences Education, 17(5), 1-4. https://doi.org/10.1187/cbe.18-02-0025

Korlat, S., Kollmayer, M., Holzer, J., Lüftenegger, M., Pelikan, E. R., Schober, B. \& Spiel, C. (2021). Gender differences in digital learning during Covid-19: Competence beliefs, intrinsic value, learning engagement, and perceived teacher support. Frontiers in Psychology 12, 1-12. https://doi.org/10.3389/fpsyg.2021.63777

Lau, Y-y., Tang, Y. M., Chau, K. Y., Vyas, L., Sandoval-Hernandez, A. \& Wong, S. (2021). Covid-19 crisis: Exploring Community of inquiry in online learning for sub-degree students. Frontiers in Psychology, 12, 114. https:// doi.org/10.3389/fpsyg.2021.679197

Lim J., \& Richardson J. C. (2020). Predictive effects of undergraduate students' perceptions of social, cognitive, and teaching presence on affective learning outcomes according to disciplines. Computers $\mathcal{E}$ Education, 161, 104063. https://doi.org/10.1016/j.compedu.2020.104063

Lombardi, M. M. (2007). Authentic learning for the 21st century: An overview. Educause Learning Initiative.

Long, C. S., Sinclair, B. B., Fraser, B. J., Larson, T. R. \& Harrell, P. E. (2021). Preservice teachers' perceptions of learning environments before and after pandemic-related course disruption. Learning Environments Research, 6, 1-15. https://doi.org/10.1007/s10984-021-09376-9

Louder, J. R. (2011). Distance learning environments at one emerging research institution in Texas: The relationship between instructor support, student interaction and collaboration, and learning [Unpublished doctoral dissertation]. Texas Tech University, Lubbock, Texas.

Mullen, G. E., \& Tallent-Runnels, M. K. (2006). Student outcomes and perceptions of instructors' demands and support in online and traditional classrooms. The Internet and Higher Education, 9(4), 257266. https://doi.org/10.1016/j.iheduc.2006.08.005

Nistor, N. (2013). Stability of attitudes and participation in online university courses: Gender and location effects. Computers \& Education, 68, 284-292. http:/ / dx.doi.org/10.1016/j.compedu.2013.05.016

Ozkok, A., Walker, S. L., \& Buyukozturk, S. (2009). Reliability and validity of a Turkish version of the DELES. Learning Environments Research, 12(3), 175-190. https://doi.org/10.1007/s10984-009-9060-0

Ozturk, E. (2012). An adaptation of the community of inquiry index: the study of validity and reliability. Elementary Education Online, 11(2), 408-422.

Palloff, R. M. \& Pratt, K. (1999). Building Learning Communities in Cyberspace: Effective strategies for the online classroom. Jossey-Bass.

Palloff, R. M., \& Pratt, K. (2009). Assessing the online learner. Jossey-Bass.

Puzziferro, M., \& Shelton, K. (2008). A model for developing high-quality online courses: Integrating a systems approach with learning theory. Journal of Asynchronous Learning Networks, 12(3-4), 119-136. https:// doi.org/10.24059/olj.v12i3.58

Reeves, T. C., Herrington, J., \& Oliver, R. (2002). Authentic activities and online learning. In A. Goody, J. Herrington, \& M. Northcote (Eds.), Quality conversations: Research and development in higher education. HERDSA.

Rizvia, S., Rienties, B., \& Khoja, S. A. (2019). The role of demographics in online learning: A decision tree based approach. Computers $\mathcal{E}$ Education, 137, 32-47. https:// doi.org/10.1016/j.compedu.2019.04.001

Roman, T. A., Callison, M., Myers, R. D., \& Berry, A. H. (2020). Facilitating authentic learning experiences in distance education: Embedding research-based practices into an online peer feedback tool. TechTrends: Linking Research and Practice to Improve Learning, 64(4), 591-605. https://doi.org/10.1007/s11528-02000496-2

Rourke, L., \& Kanuka, H. (2009). Learning in communities of inquiry: A review of the literature. Journal of Distance Education, 23(1), 19-48. 
Rubin, B., Fernandes, R., \& Avgerinou, M. D. (2013). The effects of technology on the community of inquiry and satisfaction with online courses. The Internet and Higher Education, 17, 4857. https://doi.org/10.1016/j.iheduc.2012.09.006

Shea, P., \& Bidjerano, T. (2009). Community of inquiry as a theoretical framework to foster epistemic engagement and cognitive presence in online education. Computers \& Education, 52(3), 543-553. https:// doi.org/10.1016/j.compedu.2008.10.007

Shea, P., Hayes, S., Uzuner-Smith, S., Vickers, J., Bidjerano, T., Pickett, A., Gozza-Cohen, M., Wilde, J., \& Jian, S. (2012). Learning presence: Additional research on a new conceptual element within the Community of Inquiry (CoI) framework. The Internet and Higher Education, 15(2), 8995. https://doi.org/10.1016/j.iheduc.2011.08.002

Shea, P., Hayes, S., Uzuner-Smith, S., Vickers, J., Gozza-Cohen, M., Uzuner, S., Mehta, R., Valchova, A., \& Rangan, P. (2010). A re-examination of the community of inquiry framework: Social network and content analysis. Internet and Higher Education 13, 10-21. https://doi.org/10.1016/j.iheduc.2009.11.002

Shea, P., Li, C-S., Swan, K., \& Pickett, A. (2005). Developing learning community in online asynchronous college courses: The role of teaching presence. Journal of Asynchronous Learning Networks, 9(4), 59-82. https:// doi.org/10.24059/olj.v9i4.1779

Smith, R. C. (2000). Starting with ourselves: Teacher-learner autonomy in language learning. In B. Sinclair, I. McGrath, \& T. Lamb (Eds.), Learner autonomy, teacher autonomy: New Directions (pp. 89-99). Harlow.

Snodin, N. S. (2013). The effects of blended learning with a CMS on the development of autonomous learning: A case study of different degrees of autonomy achieved by individual learners. Computers $\mathcal{E}$ Education, 61, 209-216. https://doi.org/10.1016/j.compedu.2012.10.004

Stein, D. S., Wanstreet, C. E., Glazer, H. R., Engle, C. L., Harris, R. A., Johnston, S. M., Simons, M. R, \& Trinko, L. A. (2007). Creating shared understanding through chats in a community of inquiry. The Internet and Higher Education, 10(2), 103-115. https:// doi.org/10.1016/j.iheduc.2007.02.002

Swan, K., Garrison, D. R. \& Richardson, J. C. (2009). A constructivist approach to online learning: the Community of Inquiry framework. In C. R. Payne (Ed.) Information Technology and Constructivism in Higher Education: Progressive Learning Frameworks (pp. 43-57). IGI Global.

Tabachnick, B. G., \& Fidell, L. S. (2007). Using multivariate statistics. Pearson.

Traphagan, T. W., Chiang, Y. V., Chang, H. M., Wattanawaha, B., Lee, H., Mayrath, M. C., Woo, J., Yoon, H., Jee, M. J., \& Resta, P. E. (2010). Cognitive, social and teaching presence in a virtual world and a text chat. Computers $\mathcal{E}$ Education, 55(3), 923-936. https://doi.org/10.1016/j.compedu.2010.04.003

Tsai, M.-J., \& Tsai, C.-C. (2010). Junior high school students' internet usage and self-efficacy: A reexamination of the gender gap. Computers $\mathcal{E}$ Education, 54(4), 1182-1192. https:// doi.org/10.1016/j.compedu.2009.11.004

Vonderwell, S., Liang, X., \& Alderman, K. (2007). Asynchronous discussions and assessment in online learning. Journal of Research on Technology in Education, 39(3), 309-328. https://doi.org/10.1080/15391523.2007.10782485

Walker, S. L., \& Fraser, B. J. (2005). Development and validation of an instrument for assessing distance education learning environments in higher education: The Distance Education Learning Environments Survey (DELES). Learning Environments Research, 8(3), 289-308. https://doi.org/10.1007/s10984-005-15683

Wu W.-C. V., Chen-Hsieh, J. S., \& Yang J. C. (2017). Creating an Online Learning Community in a Flipped Classroom to Enhance EFL Learners' Oral Proficiency. Educational Technology \& Society, 20(2), 142-157.

$\mathrm{Yu}, \mathrm{Z}$. (2021). The effects of gender, educational level, and personality on online learning outcomes during the Covid-19 pandemic. International Journal of Educational Technology in High Education, 18(14), 1-17. https://doi.org/10.1186/s41239-021-00252-3 
Appendix 1. The number of items, sample items and the reliability of scales

\begin{tabular}{|c|c|c|c|c|}
\hline Instrument & Scale & $\begin{array}{l}\text { Number of } \\
\text { Items }\end{array}$ & Sample Items & $\alpha^{*}$ \\
\hline \multirow{3}{*}{$\begin{array}{l}\text { Community of } \\
\text { Inquiry } \\
\text { Inventory (CoI) }\end{array}$} & $\begin{array}{l}\text { Teaching } \\
\text { Presence }\end{array}$ & 13 & $\begin{array}{l}\text { The instructor provided feedback that helped me } \\
\text { understand my strengths and weaknesses } \\
\text { relative to the course's goals and objectives. }\end{array}$ & .92 \\
\hline & Social Presence & 9 & $\begin{array}{l}\text { I felt comfortable participating in the course } \\
\text { discussions. }\end{array}$ & .88 \\
\hline & $\begin{array}{l}\text { Cognitive } \\
\text { Presence }\end{array}$ & 12 & $\begin{array}{l}\text { Online discussions were valuable in helping me } \\
\text { appreciate different perspectives. }\end{array}$ & .75 \\
\hline \multirow{8}{*}{$\begin{array}{l}\text { Distance } \\
\text { Education } \\
\text { Learning } \\
\text { Environment } \\
\text { Survey (DELES) }\end{array}$} & $\begin{array}{l}\text { Instructor } \\
\text { support }\end{array}$ & 8 & $\begin{array}{l}\text { The instructor responds promptly to my } \\
\text { questions. }\end{array}$ & .81 \\
\hline & Student & & & \\
\hline & Interaction and & 6 & I discuss my ideas with other students. & .84 \\
\hline & Personal & & & \\
\hline & Relevance & 7 & I apply my everyday experiences in class. & .82 \\
\hline & $\begin{array}{l}\text { Authentic } \\
\text { Learning }\end{array}$ & 5 & $\begin{array}{l}\text { I work on assignments that deal with real-world } \\
\text { information. }\end{array}$ & .80 \\
\hline & Active Learning & 3 & I solve my own problems. & .64 \\
\hline & $\begin{array}{l}\text { Student } \\
\text { Autonomy }\end{array}$ & 5 & I work during times that I find convenient & .83 \\
\hline
\end{tabular}

Note. *Cronbach's alpha for the adapted version 